\title{
Homocysteine and cognitive function in elderly people
}

\section{Angeles Garcia, Katherine Zanibbi}

Abstract

DeMENTIA IS HIGHLY PREVAlENT AMONG ELDERLY PEOPLE, and projections show that the number of people affected might triple over the next 50 years, mainly because of a large increase in the oldest-old segment of the population. Because of this and the disease's devastating effects, measures for the prevention and early detection of dementia are crucial. Age and years of education are among the most relevant risk factors for dementia, but in recent years the role of homocysteine has also been investigated. Homocysteine is an amino acid produced in the metabolism of methionine, a process dependent on the $\mathrm{B}$ vitamins cobalamin, vitamin $\mathrm{B}_{6}$ and folic acid. There is evidence that increased serum homocysteine levels are associated with declining cognitive function and dementia. We review this evidence in addition to the potential mechanisms through which homocysteine acts on the brain to cause cognitive dysfunction, the metabolism of homocysteine and factors associated with alteration of the normal metabolism.

CMAJ 2004;171(8):897-904

$\mathrm{D}$ ementia is characterized by a progressive deterioration of cognitive skills that leads to a decline in the ability to perform daily activities. It affects $8 \%$ of people over the age of $65^{1}$ and results in more than 60000 new cases in Canada each year. Alzheimer's disease accounts for more than $50 \%$ of cases of dementia in Canada. ${ }^{2}$ Projections for the next 50 years show that the number of patients with dementia might triple, ${ }^{3}$ mainly because of a large increase in the oldest-old segment of the population. Because of the disease's high prevalence and devastating effects on patients, caregivers and the health care system, measures for the prevention and early detection of dementia are crucial.

Age and years of education are among the most relevant risk factors for dementia, but in recent years the role of homocysteine has also been investigated. Homocysteine is an amino acid that is produced in the metabolism of methionine, a process dependent on the $\mathrm{B}$ vitamins cobalamin, vitamin $\mathrm{B}_{6}$ and folic acid. There is evidence that increased serum homocysteine levels are associated with declining cognitive function and dementia. We review this evidence in addition to the potential mechanisms through which homocysteine acts on the brain to cause cognitive dysfunction, the metabolism of homocysteine and factors associated with alteration of the normal metabolism.

\section{Population studies}

\section{Homocysteine and dementia}

An outline of the published research into homocysteine and dementia can be found in Table 1. In brief, elevated serum homocysteine levels have been found to be an independent risk factor for Alzheimer's disease. Recently, Seshadri and associates, ${ }^{8}$ in a population sample of the Framingham cohort, found that elevated levels were a graded independent risk factor for Alzheimer's disease. Other studies have shown that serum homocysteine levels are significantly higher among patients with dementia than among normal control subjects ${ }^{4-6}$ and that the levels are inversely related to cognitive function in people with dementia. ${ }^{9}$ In a recent study, however, elevated homocysteine levels were found to be more common among patients with vascular disease than among those with Alzheimer's disease. ${ }^{7}$ Whether homocysteine contributes to cerebrovascular changes or to the pathological features of Alzheimer's disease, or both, remains controversial, but regardless of the mechanisms, it appears that elevated homocysteine levels are a risk factor for dementia in older adults.

\section{Homocysteine and cognitive function scores}

As can be seen in Table 2, studies involving healthy elderly people have yielded conflicting results. Some have shown significant associations between homocysteine levels and cognitive function, ${ }^{10,12-17,19-22}$ whereas others have not. ${ }^{11,18}$ An early study involving a small sample of a healthy elderly population in Italy showed no significant correlations between the Mini-Mental State Exam (MMSE) scores and homocysteine levels. ${ }^{11}$ However, the same authors later found, in a much larger population group, that the risk of lower MMSE scores increased with increasing levels of plasma homocysteine and that homocysteine had an independent graded association with cognitive impairment. ${ }^{16}$ Most longitudinal studies have found associations between cognitive function scores and homocysteine levels. In a cohort study, homocysteine levels at baseline and increases in levels over a mean of 2.3 years were found to be related to changes in executive function scores. ${ }^{17}$

The timeframe for changes in cognitive function to occur in relation to homocysteine levels may be long, which 
may leave a substantial window of opportunity for preventive interventions.

In a 35-day trial of B vitamins versus placebo, Bryan and colleagues $^{23}$ found an improvement in some memory performance scores in a subgroup of older women. However, contrary to expectations, the overall cognitive and mood changes related to the treatment were felt to be minimal.

\section{Mechanisms of action of homocysteine in the brain}

Homocysteine is metabolized through 2 different pathways: the methionine synthase pathway and the cystathionine pathway (Fig. 1). The effects of homocysteine in the brain are multiple but can be broadly divided into neurotoxic and vascular effects (see Box 1).

The evidence for the neurotoxic effects comes largely from in vitro studies. ${ }^{25,26}$ It has been shown in vitro that ho- mocysteine acts as an agonist on the glutamate-binding site and as a partial antagonist on the glycine-binding site of the $\mathrm{N}$-methyl-D-aspartate (NMDA) receptor. Under conditions of elevated glycine concentrations, such as in stroke or head trauma, homocysteine at a concentration of $10 \mu \mathrm{mol} / \mathrm{L}$ had a neurotoxic effect through hyperstimulation of the NMDA receptor that resulted in an excess influx of calcium ions and production of reactive oxygen species.

As in other parts of the body, homocysteine has direct and indirect vascular effects, and an elevation in homocysteine levels has been recognized as an independent cardiovascular risk factor. ${ }^{27,28}$ Elevated levels induce atherogenesis by directly increasing formation of reactive oxygen species and by promoting oxidation of low-density lipoprotein..$^{29,30}$ Reactive oxygen species alter smooth muscle function and promote proliferation of vascular smooth muscle cells. Furthermore, homocysteine has been shown to increase platelet aggregation, ${ }^{29,30}$ which contributes to the occurrence of clinically apparent and silent brain infarcts.

\section{Table 1: Studies investigating relation between homocysteine and dementia}

\begin{tabular}{|c|c|c|c|c|c|}
\hline Study & Study population & Study design & $\begin{array}{l}\text { Cognitive assessment/ } \\
\text { diagnostic criteria }\end{array}$ & Results & Comment \\
\hline Stewart, $2002^{4}$ & $\begin{array}{l}238 \text { African- } \\
\text { Caribbean adults } \\
\text { aged } 55-75 \mathrm{yr}\end{array}$ & Cross-sectional & $\begin{array}{l}\text { CERAD; WHO; } \\
\text { MMSE }\end{array}$ & $\begin{array}{l}\text { tHcy level > } 13.85 \mu \mathrm{mol} / \mathrm{L} \\
\text { associated with cognitive } \\
\text { impairment (OR 2.86, } \\
95 \% \mathrm{Cl} 1.33-6.13 \text { ) }\end{array}$ & $\begin{array}{l}\text { OR adjusted for age, } \\
\text { occupation, hypertension, } \\
\text { diabetes, physical activity, } \\
\text { and levels of cholesterol, } \\
\text { triglycerides and fibrinogen }\end{array}$ \\
\hline Clarke, $1998^{5}$ & $\begin{array}{l}272 \text { patients } \\
\text { aged }>55 \mathrm{yr} ; \\
\text { control-matched } \\
\text { comparison }\end{array}$ & Case-control & CERAD, NINDS & $\begin{array}{l}\text { tHcy }>14.0 \mu \mathrm{mol} / \mathrm{l} \\
\text { associated with } \mathrm{AD}(\mathrm{OR} \\
2.0,95 \% \mathrm{Cl} 1.1-3.4)\end{array}$ & $\begin{array}{l}\text { OR adjusted for age, sex, } \\
\text { smoking, social class and } \\
\text { apolipoprotein E }\end{array}$ \\
\hline
\end{tabular}

McCaddon $1998^{6}$

60 patients with DSM-III-R criteria for $A D$

Miller, $2002^{7}$

80 patients with

Case-control

possible or

probable AD

Seshadri, 2002

1092 dementiafree patients in Framingham cohort aged

Case-control

68-97 yr

Vital Trial

Collaborative

Group, $2003^{9}$
149 patients with dementia or mild cognitive impairment
Prospective cohort (median follow-up $8 \mathrm{yr}$ )

Intervention study of ASA and vitamin supplements on serum biomarkers of dementia
tHcy level inversely related to scores on cognitive testing

NINCDS-ADRDA

thcy level $>12 \mu \mathrm{mol} / \mathrm{L}$ associated with vascular disease (OR $10.0,95 \% \mathrm{Cl}$ 1.2-82) but not with AD (OR 2.2, 95\% Cl 0.31-16)

thcy level associated with increased risk of dementia and $\mathrm{AD}$ (RR 1.4, 95\% Cl 1.1-1.9 per 1 SD increase in log-transformed tHcy level)

MMSE, DSM IV criteria, Clinical Dementia Rating Scale, NINCDSADRDA

MMSE, TICS-M, DSM IV criteria
At baseline, thcy level inversely associated with cognitive scores
Results adjusted for age, sex, folate and cobalamin levels, smoking and hypertension. Effect of tHcy and cobalamin found to be interrelated

OR adjusted for age, sex, and levels of red blood cell folate, plasma $B_{12}$, serum creatinine and serum thyroid stimulating hormone

RR adjusted for age, sex, apolipoprotein E genotype, education level, history of stroke, smoking, alcohol intake, diabetes, body mass index and systolic blood pressure

Results adjusted for age

\footnotetext{
Note: $\mathrm{AD}=$ Alzheimer's disease, CAMDEX = Cambridge Examination for Mental Disorders of the Elderly, CERAD = Consortium to Establish a Registry for Alzheimer's Disease, $\mathrm{Cl}=$ confidence interval, DSM = Diagnostic and Statistical Manual of Mental Disorders, MMSE = Mini-Mental Status Exam, NINCDS-ADRDA $=$ National Institute of Neurological and Communication Disorders and Stroke/Alzheimer's Disease and Related Disorders Association, NINDS $=$ National Institute of Neurological Disorders, $\mathrm{OR}=$ odds ratio, RR $=$ relative risk, $\mathrm{SD}=\mathrm{standard}$ deviation, $\mathrm{tHcy}=$ homocysteine, TICS-M = Telephone Interview of Cognitive Status, $\mathrm{WHO}=$ World Health Organization.
} 
An elevation in homocysteine levels has been found to be an independent risk factor for recurrent stroke ${ }^{31}$ in patients with pre-existing coronary artery disease $\mathrm{e}^{32}$ and in other populations. ${ }^{33,34}$ It is also related to white matter abnormalities. ${ }^{35}$ In the Rotterdam Scan Study, ${ }^{36}$ an association between homocysteine levels, silent brain infarcts and white matter lesions was found. The risk of silent brain infarcts, the severity of periventricular white matter lesions and the extent of the subcortical white matter lesions increased with increasing levels of homocysteine, after adjustment for other risk factors, with an overall risk of silent brain infarcts or severe white matter lesions of 1.35 per standard deviation increase in homocysteine level (95\% confidence interval [CT 1.161.58). Interestingly, the risk of silent brain infarcts and severe white matter lesions was already significantly increased among subjects whose homocysteine levels were within the upper normal range (between 9.9 and $13.7 \mu \mathrm{mol} / \mathrm{L}$ ) compared with subjects whose levels were in the lower normal range $(<8.5 \mu \mathrm{mol} / \mathrm{L})$. Subjects whose levels were above the normal range had the highest odds ratio for all MRIdetected abnormalities (odds ratio 3.0, 95\% CI 1.8-5.2). ${ }^{36}$

In addition to stroke, increased homocysteine levels have been shown to be related to increased cortical and hippocampal atrophy. A recent study showed that subjects with higher homocysteine levels had more cortical and hippocampal atrophy than those with lower levels. ${ }^{37}$ Previous results from the Nun study ${ }^{38}$ showed that cerebral atrophy was also related to folic acid levels. In a recent review article, Lokk $^{39}$ referred to homocysteine as the most sensitive marker of cobalamin/folic acid metabolic function and the factor most strongly correlated with parameters of cognition. In contrast, Sachdev and associates ${ }^{40}$ in a study that included only 36 subjects, found that homocysteine was a significant determinant of the ventricular-brain ratio (an index of brain atrophy) but that it did not contribute to white matter abnormalities or cortical atrophy. Hogervorst and associates $^{41}$ found that white matter lesions were more prevalent among patients with Alzheimer's disease than among age- and sex-matched control subjects, and the odds ratio for leukoaraiosis increased significantly for each increase of $5 \mu \mathrm{mol} / \mathrm{L}$ in homocysteine level.

The relative impact of the different mechanisms by which intracellular actions of homocysteine may occur is unknown, and the final in vivo effects might depend on other related intracellular substances, products of the same metabolic pathways, such as S-adenosylhomocysteine.

\section{Factors influencing homocysteine levels}

Homocysteine levels are influenced by B vitamins, genetic factors and other factors such as age.

\section{B vitamins}

$\mathrm{B}$ vitamins are essential nutrients because of their role in the synthesis and repair of DNA. The B vitamins cobala- min, vitamin $B_{6}$ and folic acid affect homocysteine levels through their roles as cofactors for the enzymes involved in methionine metabolism. Their levels are inversely related, with plasma homocysteine levels increasing as vitamin B concentrations decrease. ${ }^{42}$

Epidemiological studies have shown that the prevalence of cobalamin deficiency increases with age. With a normal cutoff point of $200 \mathrm{pg} / \mathrm{mL}(150 \mathrm{pmol} / \mathrm{L})$, the prevalence of low serum cobalamin levels among elderly people ranges from $6 \%$ to $16 \%{ }^{43-46}$ Cobalamin deficiency may cause multiple abnormalities, including megaloblastic anemia, gastrointestinal changes, peripheral neuropathy, subacute combined degeneration, depression and cognitive impairment. Traditionally, megaloblastic anemia has served as a surrogate marker for clinical investigation of cobalamin deficiency. However, the effects of cobalamin deficiency at the hematological and neurological levels are not parallel; in fact, the concurrent presentation of both hematological and neurological abnormalities is found in only $41 \%$ of cases. ${ }^{47}$ Moreover, serum cobalamin levels are not the best indicators of cobalamin function at the tissue level. Impaired cellular cobalamin and folic acid function causes an increase in homocysteine, methylmalonic acid and methylcitric acid levels. Elevated levels of any of these metabolites can be found in up to $30 \%$ of healthy elderly people living in the community $^{44,45,48,49}$ and will return to normal after supplementation therapy. ${ }^{50}$ In a cohort study, participants who were taking $25 \mu \mathrm{g}$ or more of cobalamin daily had a significantly lower risk of elevated metabolite levels than participants who did not take multivitamin supplements..$^{51}$ Moreover, in a randomized, placebo-controlled pilot study of treatment with monthly injections of cobalamin for 6 months, we found that homocysteine levels were significantly lower in the treatment group than in the placebo group, even though all of the subjects had normal or elevated red blood cell (RBC) folate levels..$^{22}$

Piridoxine (vitamin $\mathrm{B}_{6}$ ) is a cofactor in the metabolism of homocysteine through the transsulfuration pathway (Fig. 1). The impact of vitamin $B_{6}$ treatment on homocysteine levels is controversial. In one study high-dose vitamin $\mathrm{B}_{6}$ therapy was reported to be effective in reducing cardiovascular events in patients with elevated homocysteine levels due to cystathionine B synthase abnormalities; ${ }^{53}$ however, such treatment was not effective in reducing elevated homocysteine levels in adults with mild elevations in homocysteine..$^{54}$ In a recent case-control study, Kelly and associates $^{55}$ found a significantly strong independent association between low levels of vitamin $\mathrm{B}_{6}$ and stroke or transient ischemic attack but not between elevated homocysteine levels and vascular events.

\section{Effects of folic acid fortification of grain products}

Folic acid fortification of grain products to prevent neural tube defects in newborns became mandatory in Canada and the United States in 1998. This has resulted in 
increased levels of serum folic acid and of RBC folate in the entire population. ${ }^{56}$ The effects of these increases on homocysteine levels in the elderly population are largely unknown, but interesting data have started to emerge. A Chilean study recently reported that folic acid fortification of flour had a moderate lowering effect on homocysteine levels in the elderly population (mean age 74.3 years). ${ }^{57} \mathrm{~A}$ retrospective cross-sectional study in Ontario ${ }^{58}$ showed that, shortly after folic acid fortification began, RBC folate and serum folate levels were higher than expected before fortification when compared with historical data. However, RBC folate and serum folate levels for that population before fortification were unavailable for comparison. A recent study showed that $\mathrm{RBC}$ folate levels in older people living independently in Ontario have continued to increase significantly every year since fortification was started and are currently 2.5 times higher than the levels in $1998 .^{59}$ A study of the Framingham Offspring cohort showed that fortification with an average of $140 \mu \mathrm{g}$ of folic acid per $100 \mathrm{~g}$ of cereal grain product resulted in a signifi-

Table 2: Studies investigating relation between homocysteine and cognitive function scores

\begin{tabular}{|c|c|c|c|c|c|}
\hline Study & Study population & Study design & $\begin{array}{c}\text { Cognitive } \\
\text { assessment }\end{array}$ & Results & Comment \\
\hline $\begin{array}{l}\text { Riggs et al, } \\
1996^{10}\end{array}$ & $\begin{array}{l}70 \text { people aged } \\
54-81 \mathrm{yr} \text { in } \\
\text { Normative Aging } \\
\text { Study }\end{array}$ & $\begin{array}{l}\text { Cross section of } \\
\text { prospective cohort }\end{array}$ & CERAD, NES2 & $\begin{array}{l}\text { tHcy levels } \\
>12.6 \mu \mathrm{mol} / \mathrm{L} \\
\text { associated with poorer } \\
\text { spatial copying skills. } \\
\text { No relation found } \\
\text { between tHcy levels } \\
\text { and perceptual speed, } \\
\text { spatial reasoning or } \\
\text { language abilities }\end{array}$ & $\begin{array}{l}\text { Concluded that tHcy may } \\
\text { have differential effects on } \\
\text { cognitive abilities }\end{array}$ \\
\hline
\end{tabular}

$\begin{array}{ll}\text { Ravaglia et al, } & 54 \text { people aged } \\ 2000^{11} & >65 \mathrm{yr} \text { in } \\ & \text { Conselice Study }\end{array}$

Budge et al, $2002^{12}$

Duthie et al, $2002^{13}$

Miller et al, $2003^{15}$

158 communitydwelling people aged 60-91 yr

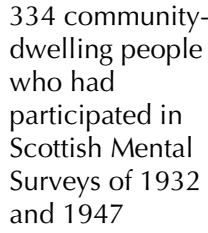
dwelling people who had participated in Scottish Mental Surveys of 1932 and 1947

Prins et al, $2002^{14} \quad 1077$ people aged 60-90 yr in Rotterdam Scan Study community-

Cross section of
prospective cohort

Cross section of CAMCOG, prospective cohort prospective cohort MMSE, GDS

Cross section

Cross section of Substitution Task,

Cross section of prospective cohort dwelling people aged $\geq 60 \mathrm{yr}$ in Sacramento Area Latino Study on Aging
MMSE, clockdrawing test, prose memory test, Corsi blocktapping task, Mental Deterioration Battery

MMSE, NART RPM, AVLT, WAIS

Abbreviated Stroop test, Letter-Digit Verbal fluency test, PPMST, Modified Rey's test

No association found between tHcy levels and cognitive test scores

\section{Higher tHcy levels} associated with lower memory scores per $\mu \mathrm{mol} / \mathrm{L}$ (OR $1.15,95 \% \mathrm{Cl}$ 1.10-1.27)

tHcy levels negatively associated with scores on RPM, WAIS in older cohort with higher tHcy levels (mean $10.9 \mu \mathrm{mol} / \mathrm{L}, 95 \% \mathrm{Cl}$ 10.1-11.5)

Patients with thcy $>14 \mu \mathrm{mol} / \mathrm{L}$ had lower scores for global cognitive function (difference-0.20, 95\% $\mathrm{Cl}-0.30$ to -0.11 )

3MSE, verbal and Inverse relation visual memory tests, object naming, conceptualizatio $\mathrm{n}$ and attention span tests
Results adjusted for age, sex, education level, smoking status, alcohol or coffee consumption, and previous cardiovascular disease

OR adjusted for age, sex, serum cystatin $\mathrm{C}$ level and systolic blood pressure

Results adjusted for childhood intelligence quotient

Results adjusted for age, sex, education level, depression, serum creatinine level

Multiple linear regression model inlcuded folate, cobalamin, creatinine, age, sex, education and acculturation 
cant increase in $\mathrm{RBC}$ folate levels and a decrease in the proportion of people with suboptimal RBC folate levels. ${ }^{60,61}$ The same authors estimated that fortification resulted in a mean increase in folic acid intake that was about twice as large as previously projected. ${ }^{56}$ To determine the effects of increasing levels of folic acid and RBC folate on homocysteine levels in the elderly population, it might be relevant to observe the results of coexisting high levels of RBC folate and marginally low levels of cobalamin on homocysteine in this population.

\section{Genetic factors}

Remethylation of homocysteine to methionine requires the enzyme 5,10-methylenetetrahydrofolate reductase (MTHFR). MTHFR catalyzes the reduction of 5,10methylenetetrahydrofolate to 5-methyltetrahydrofolate, the carbon donor in the remethylation reaction. A common MTHFR gene mutation (C-to-T substitution at codon 677, or C677T) results in increased thermolability and decreased activity of the MTHFR enzyme. People

\section{Table 2 continued}

\begin{tabular}{|c|c|c|c|c|c|}
\hline Study & Study population & Study design & $\begin{array}{l}\text { Cognitive } \\
\text { assessment }\end{array}$ & Results & Comment \\
\hline $\begin{array}{l}\text { Ravaglia et al, } \\
2003^{16}\end{array}$ & $\begin{array}{l}650 \text { community- } \\
\text { dwelling people } \\
\text { aged 65-91 yr (mean } \\
73 \text { yr) with normal } \\
\text { cognitive function in } \\
\text { Conselice Study }\end{array}$ & $\begin{array}{l}\text { Population- } \\
\text { based study }\end{array}$ & MMSE & $\begin{array}{l}\text { Inverse relation between odds } \\
\text { of tHcy level > } 15 \mu \mathrm{mol} / \mathrm{L} \\
\text { and MMSE scores }\end{array}$ & $\begin{array}{l}\text { Results adjusted for age, } \\
\text { education level, income, } \\
\text { serum creatinine level, serum } \\
\text { vitamin B index, active } \\
\text { lifestyle, and coffee and meat } \\
\text { consumption }\end{array}$ \\
\hline $\begin{array}{l}\text { Garcia et al, } \\
2004^{17}\end{array}$ & $\begin{array}{l}281 \text { community- } \\
\text { dwelling volunteers } \\
\text { aged }>65 \mathrm{yr}\end{array}$ & Cross section & $\begin{array}{l}\text { Stroop, Mattis DRS, } \\
\text { CVLT }\end{array}$ & $\begin{array}{l}\text { Subjects with elevated tHcy } \\
\text { levels }(>13.9 \mu \mathrm{mol} / \mathrm{L}) \text { had } \\
\text { lower Stroop scores than those } \\
\text { with normal tHcy levels in } \\
\text { univariate analysis }(p<0.05)\end{array}$ & $\begin{array}{l}\text { Strongest association found } \\
\text { between methylcitric acid } \\
\text { and cognitive scores }\end{array}$ \\
\hline $\begin{array}{l}\text { Kalmijn et al, } \\
1999^{18}\end{array}$ & $\begin{array}{l}702 \text { community- } \\
\text { dwelling people } \\
\text { aged }>55 \mathrm{yr} \text { in } \\
\text { Rotterdam Study }\end{array}$ & $\begin{array}{l}\text { Prospective } \\
\text { cohort; mean } \\
\text { follow-up } \\
2.7 \mathrm{yr}\end{array}$ & MMSE & $\begin{array}{l}\text { No association between tHcy } \\
\text { and cognitive impairment } \\
\text { (highest v. lowest tertile, OR } \\
0.91,95 \% \mathrm{Cl} 0.52-1.58 \text { ) }\end{array}$ & $\begin{array}{l}\text { OR adjusted for age, sex, } \\
\text { education level and baseline } \\
\text { MMSE score }\end{array}$ \\
\hline $\begin{array}{l}\text { McCaddon et } \\
\text { al, } 2001^{19}\end{array}$ & $\begin{array}{l}32 \text { community- } \\
\text { dwelling people } \\
\text { aged }>65 \mathrm{yr}\end{array}$ & $\begin{array}{l}\text { Prospective } \\
\text { cohort; } 5-y r \\
\text { follow-up }\end{array}$ & $\begin{array}{l}\text { MMSE, } \\
\text { ADAS-Cog }\end{array}$ & $\begin{array}{l}\text { Baseline tHcy predicted } \\
\text { MMSE scores }(p=0.001) \text { and } \\
\text { ADAS-Cog scores } \\
(p=0.01) \text { at } 5-y r \text { follow-up }\end{array}$ & $\begin{array}{l}\text { Results adjusted for age and } \\
\text { education. }\end{array}$ \\
\hline $\begin{array}{l}\text { Dufouil et al, } \\
2003^{20}\end{array}$ & $\begin{array}{l}1241 \text { people aged }> \\
60 \mathrm{yr} \text { in } \\
\text { Epidemiology of } \\
\text { Vascular Aging } \\
\text { Study }\end{array}$ & $\begin{array}{l}\text { Prospective } \\
\text { cohort; } 4-y r \\
\text { follow-up }\end{array}$ & $\begin{array}{l}\text { MMSE, } \\
\text { Trail Making Test } \\
\text { Part B, Digit } \\
\text { Symbol } \\
\text { Substitution Test } \\
\text { from the WAIS, } \\
\text { Finger Tapping } \\
\text { Test }\end{array}$ & $\begin{array}{l}\text { Odds of cognitive decline } 2.8 \\
(95 \% \mathrm{Cl} 1.2-6.2) \text { in patients } \\
\text { with tHcy level } \\
\geq 15 \mu \mathrm{mol} / \mathrm{L}\end{array}$ & $\begin{array}{l}\text { OR adjusted for age, sex, } \\
\text { education level, baseline } \\
\text { cognition, body mass index, } \\
\text { alcohol consumption, } \\
\text { smoking, hypertension, } \\
\text { hypercholesterolemia, } \\
\text { glycemix status, history of } \\
\text { vascular disease, and folate } \\
\text { and } B_{12} \text { levels }\end{array}$ \\
\hline $\begin{array}{l}\text { Teunissen et al, } \\
2003^{21}\end{array}$ & $\begin{array}{l}144 \text { normal aging } \\
\text { adults ( } 30-80 \mathrm{yr} \text { at } \\
\text { baseline) }\end{array}$ & $\begin{array}{l}\text { Prospective } \\
\text { cohort; } 6-y r \\
\text { follow-up }\end{array}$ & $\begin{array}{l}\text { WLT, } \\
\text { LDCT, } \\
\text { Stroop }\end{array}$ & $\begin{array}{l}\text { tHcy levels inversely } \\
\text { correlated with performance } \\
\text { on WLT at baseline but not at } \\
\text { follow-up. No relation } \\
\text { between tHcy levels and } \\
\text { results of other cognitive tests }\end{array}$ & $\begin{array}{l}\text { Results adjusted for age, sex } \\
\text { and education level }\end{array}$ \\
\hline $\begin{array}{l}\text { Garcia et al (in } \\
\text { press) }\end{array}$ & $\begin{array}{l}180 \text { normal } \\
\text { community-dwelling } \\
\text { people aged } \geq 65 \mathrm{yr}\end{array}$ & $\begin{array}{l}\text { Prospective } \\
\text { cohort; mean } \\
\text { follow-up } \\
2.3 \mathrm{yr}\end{array}$ & $\begin{array}{l}\text { Stroop, Mattis DRS, } \\
\text { CVLT }\end{array}$ & $\begin{array}{l}\text { Rate of increase in tHcy } \\
\text { levels correlated with rate of } \\
\text { decline in Stroop scores }\end{array}$ & $\begin{array}{l}\text { Results adjusted for age, } \\
\text { education level, time interval } \\
\text { between } 2 \text { visits, cobalamin } \\
\text { and red blood cell folate } \\
\text { levels, diabetes and } \\
\text { hypertension }\end{array}$ \\
\hline
\end{tabular}

Note: ADAS-Cog = Alzheimer's Disease Assessment Scale, cognitive component, AVLT = Auditory Verbal Learning Test, CERAD = Consortium to Establish a Registry for Alzheimer's Disease, CAMCOG = Cambridge Examination for Mental Disorders of the Elderly, CVLT = California Verbal Learning Test, GDS = Geriatric Depression Scale, LDCT = Letter-Digit Coding Test, Mattis DRS $=$ Mattis Dementia Rating Scale, MMSE = Mini-Mental Status Exam, NART = National Adult Reading Test, NES = Neurobehavioural Evaluation System, NINCDS-ADRDA = National Institute of Neurological and Communication Disorders and Stroke/Alzheimer's Disease and Related Disorders Association, PPMST = Paper and Pencil Memory Scanning Task, RPM = Raven's Progrssive Matrices, Stroop = Stroop Colour-Word Test, 3MSE = Modified Mini-Mental Status Exam, TICS-M = Telephone Interview of Cognitive Status, WAIS = Wechsler Adult Intelligence Scale, WLT = Word Learning Test. 
homozygous for the C677T variant exhibit significantly reduced MTHFR activity and higher levels of homocysteine than do heterozygous and normal subjects. ${ }^{62}$ The MTHFR C677T mutation is common and has been described in younger patients with cardiovascular disease. ${ }^{63}$ Although this mutation might increase the risk of stroke and vascular dementia, ${ }^{64}$ its influence on homocysteine levels in the elderly population is unclear..$^{65}$ There is evidence to suggest that the effects of this mutation on homocysteine levels may be most evident when they are combined with low folate levels, and possibly also low riboflavin levels, in the younger population. ${ }^{66-68}$ Although homozygous patients have a shorter life expectancy than heterozygous patients, it is reasonable to expect that heterozygous subjects might reach older age and have higher homocysteine levels than subjects without the mutation. The prevalence of the heterozygous mutation among Canadians over 55 years old has been estimated to be about $41 \% .{ }^{69}$ The relation of this mutation to dementia is being investigated.

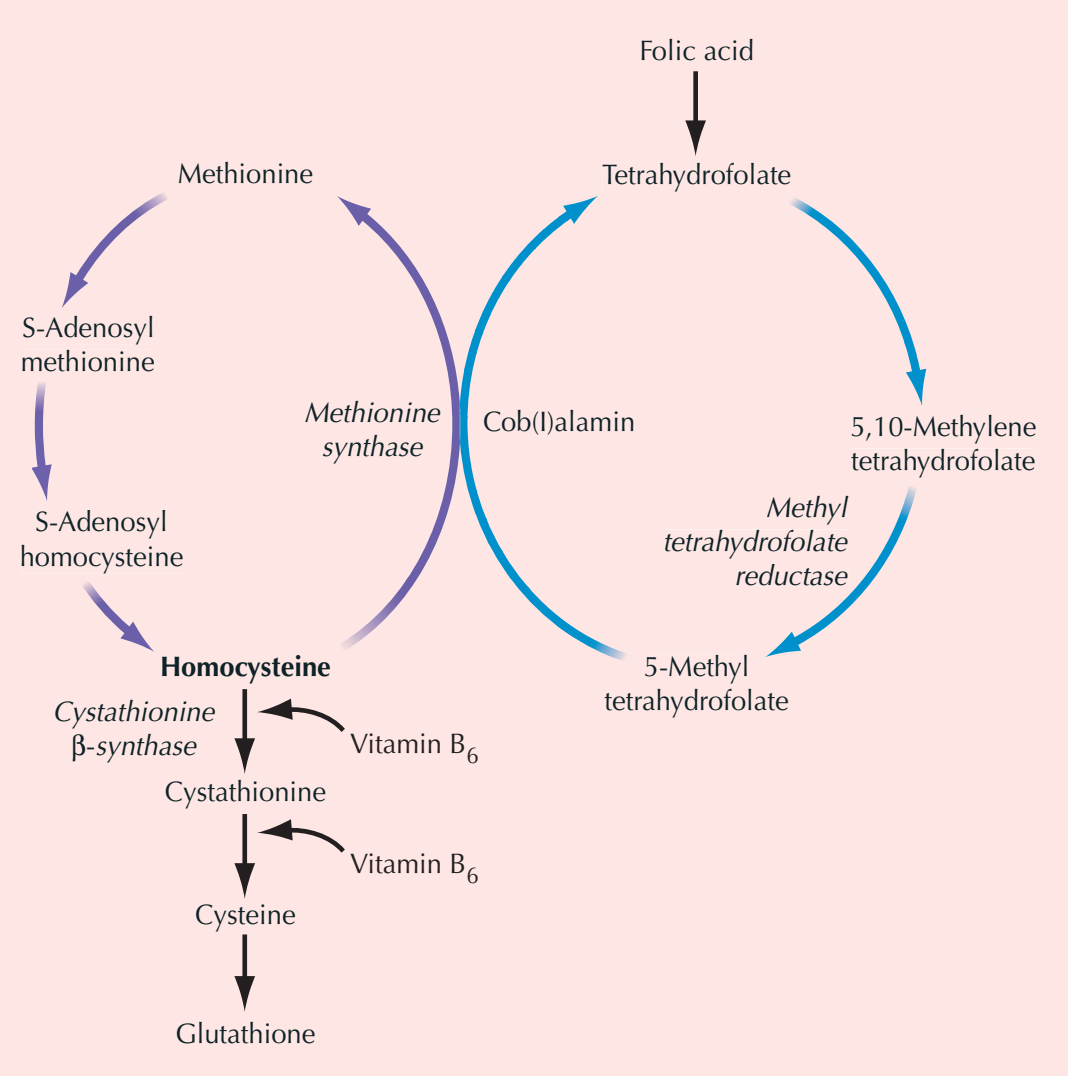

Fig. 1: Normal metabolism of homocysteine. Homocysteine is metabolized through 2 pathways: the methionine synthase pathway and the cystathionine pathway. It has been proposed that impaired remethylation of homocysteine produces an increase of intracellular homocysteine that is toxic to neurons, and a decrease in S-adenosyl methionine. Impairment of this reaction would occur in states of cerebral oxidative stress, which would augment oxidation of an intermediate form of vitamin $B_{12}$ (cob[I]alamin) produced in the methionine synthase reaction and compromise the conversion of the vitamin to its metabolically active form. ${ }^{24}$

\section{Other factors}

Besides genetic factors and those related to B vitamins, age is the single most important determinant of homocysteine levels in the general population. Levels remain relatively stable during the first 4 decades of life and increase steadily thereafter, particularly after the age of $70 .^{70,71} \mathrm{Ho}-$ mocysteine levels in people over 85 are on average double the levels in people less than 40 , and the prevalence of elevated homocysteine levels is significantly higher among older people than among younger people. ${ }^{71}$ Sex has an influence on homocysteine levels among younger adults, with men having slightly higher levels on average than women. ${ }^{71}$ This sex-specific difference may be due to estrogen levels. One study showed that the mean serum total homocysteine level was significantly lower among postmenopausal women who were taking estrogen replacement therapy $(9.5 \mu \mathrm{mol} / \mathrm{L}$ [95\% CI 8.9-10.1]) than among postmenopausal women who were not taking estrogen therapy $(10.7 \mu \mathrm{mol} / \mathrm{L}$ [95\% CI 10.3-11.1]) and men in the same age range $(10.4 \mu \mathrm{mol} / \mathrm{L}[95 \% \mathrm{CI}$ $9.8-11.0])^{72}$

Other factors that may have a significant impact on homocysteine levels in specific population groups include renal function, serum albumin levels and the use of diuretics. ${ }^{73}$

\section{Conclusion and future directions}

There is evidence that elevated homocysteine levels are related to vitamin B deficiency, cognitive decline and dementia, but there is no proof at present that treatment with $B$ vitamins will reverse $\operatorname{cog}$ nitive deterioration or dementia, even though it might return homocysteine levels to normal. Malouf and associates ${ }^{74}$ recently reviewed the results of 2 pilot studies of B vitamins in patients with dementia. No significant cognitive improvements were found with this treatment despite successful reduction of homocysteine levels. More definitive answers should come from an ongoing long-term double-blind, multicentre, randomized placebo-controlled trial involving patients with dementia that will be completed in 2005/06.

Given our knowledge of the mechanisms of action of homocysteine, it is possible to speculate that the effects of elevated homocysteine on the brain may be irreversible, in which case, once the pathological changes have appeared, the 


\section{Box 1: Effects of elevated homocysteine levels in the brain}

Neurotoxic

- Hyperactivation of $\mathrm{N}$-methyl-D-aspartate receptors

- Apoptosis

Vascular

- Increased proliferation of smooth muscle cells

- Increased platelet aggregation

- Increased number of strokes and white matter lesions

beneficial effects of vitamin supplementation therapy in patients with dementia would be limited. However, as with risk factors for other medical conditions, detection of elevated homocysteine levels in older adults and treatment with B vitamins at an early stage, before cognitive decline is clinically apparent and pathological changes have appeared, may be an effective intervention. Such primary prevention trials are worth investigating.

This article has been peer reviewed.

The authors are with the Department of Medicine, Queen's University, Kingston, Ont. Competing interests: None declared.

Contributors: Both authors contributed to the bibilographic research, preparation, writing and editing of the article.

\section{References}

1. Canadian Study of Health and Aging Working Group. Canadian study on health and aging: study methods and prevalence of dementia. CMA7 1994; 150(6):899-913.

2. Canadian Study of Health and Aging Working Group. The incidence of dementia in Canada. Neurology 2000;55:66-73.

3. Hebert LE, Scherr PA, Bienias JL, Bennett DA, Evans DA. Alzheimer disease in the US population: prevalence estimates using the 2000 census. Arch Neurol 2003;60:1119-22.

4. Stewart R, Asonganyi B, Sherwood R. Plasma homocysteine and cognitive impariment in an older British African-Caribbean population. 7 Am Geriatr Soc 2002;50:1227-32.

5. Clarke R, Smith D, Jobst K, Refsum H, Sutton L, Ueland PM. Folate, vitamin B-12, and serum total homocysteine levels in confirmed Alzheimer's disease. Arch Neurol 1998;55:1449-55.

6. McCaddon A, Davies G, Hudson P, Tandy S, Cattell H. Total serum homocysteine in senile dementia of Alzheimer type. Int 7 Geriatr Psych 1998;13: 235-9.

7. Miller JW, Green R, Mungas DM, Reed BR, Jagust WJ. Homocysteine, vitamin B6, and vascular disease in AD patients. Neurology 2002;58:1471-5.

8. Seshadri S, Beiser A, Selhub J, Jacques PF, Rosenberg IH, D'Agostino RB, et al. Plasma homocysteine as a risk factor for dementia and Alzheimer's dissease. N Engl f Med 2002;346:476-83.

9. Vital Trial Collaborative Group. Effect of vitamins and aspirin on markers of platelet activation, oxidative stress and homocysteine in people at high risk of dementia. 7 Intern Med 2003;254:67-75.

10. Riggs KM, Spiro A III, Tucker K, Rush D. Relations of vitamin B12, vitamin B6, folate and homocysteine to cognitive performance in the normative aging study. Am 7 Clin Nutr 1996;63:306-14.

11. Ravaglia G, Forti P, Maioli F, Zanardi V, Delmonte E, Grossi G, et al. Blood homocysteine and vitamin $B$ levels are not associated with cognitive skills in healthy normally aging subjects. 7 Nutr Health Aging 2000;4:218-22.

12. Budge MM, de Jager C, Hogervorst E, Smith AD. Total plasma homocysteine, age, systolic blood pressure, and cognitive performance in older people. 7 Am Geriatr Soc 2002;50:2014-8.

13. Duthie SJ, Whalley LJ, Collins AR, Leaper S, Berger K, Deary IJ. Homocys- teine, $\mathrm{B}$ vitamin status, and cognitive function in the elderly [published erratum in Am 7 Clin Nutr 2003;77:523]. Am 7 Clin Nutr 2002;75:908-13.

14. Prins ND, den Heijer T, Hofman A, Koudstaal PJ, Jolles J, Clarke R, et al. Homocysteine and cognitive function in the elderly. The Rotterdam Scan Study. Neurology 2002;59:1375-80.

15. Miller JW, Green R, Ramos MI, Allen LH, Mungas DM, Jagust WJ, et al. Homocysteine and cognitive function in the Sacramento Area Latino Study on Aging. Am 7 Clin Nutr 2003;78:441-7.

16. Ravaglia G, Forti PL, Maioli F, Muscari A, Sacchetti L, Arnone G, et al. Homocysteine and cognitive function in healthy elderly community dwellers in Italy. Am 7 Clin Nutr 2003;77:668-73.

17. Garcia A, Haron Y, Evans L, Smith M, Freedman M, Roman G. Metabolic markers of cobalamin deficiency and cognitive function in normal older adults. 7 Am Geriatr Soc 2004;52:66-71.

18. Kalmijn S, Launer LJ, Lindemans J, Bots ML, Hojman A, Breteler MM. Total homocysteine and cognitive decline in a community-based sample of elderly subjects. The Rotterdam Study. Am F Epidemiol 1999;150:283-9.

19. McCaddon A, Hudson P, Davies G, Hughes A, Williams JH, Wilkinson C. Homocysteine and cognitive decline in healthy elderly. Dement Geriatr Cogn Disord 2001;12:309-13.

20. Dufouil C, Alperovitch A, Ducros V, Tzourio C. Homocysteine, white matter hyperintensities, and cognition in healthy elderly people. Ann Neurol 2003 53:214-21.

21. Teunissen CE, Blom AH, Van Boxtel PJ, Bosma H, de Bruijn C, Jolles J, et al. Homocysteine: a marker for cognitive performance? A longitudinal followup study. 7 Nutr Health Aging 2003;7:153-9.

22. Garcia A, Haron Y, Pulman K, Hua L, Freedman M. Increases in homocysteine are related to worsening of Stroop scores in normal elderly subjects. A prospective follow-up study. $\mathcal{F}$ Gerontol A Biol Sci Med Sci. In press.

23. Bryan J, Calvaresi E, Hughes D. Short-term folate, vitamin B-12 or vitamin B-6 supplementation slightly affects memory performance but not mood in women of various ages. F Nutr 2002;132:1345-56.

24. McCaddon A, Regland B, Hudson P, Davies G. Functional vitamin B(12) deficiency and Alzheimer's disease. Neurology 2002;58:1395-9.

25. Kruman II, Culmsee C, Chan SL, Kruman Y, Guo Z, Penix L, et al. Homocysteine elicits a DNA damage response in neurons that promotes apoptosis and hyper sensitivity to exitotoxicity. 7 Neurosci Res 2000;20:6920-6.

26. Lipton SA, Kim WK, Choi YB, Kumar S, D'Emilia DM, Rayudu PV, et al Neurotoxicity associated with dual actions of homocysteine at the N-methylD-aspartate receptor. Proc Natl Acad Sci USA 1997;94:5923-8.

27. The European Concerted Action Project. Plasma homocysteine as a risk factor for vascular disease. FAMA 1997;277:1775-81.

28. The Homocysteine Studies Collaboration. Homocysteine and risk of ischemic heart disease and stroke: a meta-analysis. 7AMA 2002;288:2015-22.

29. Welch GN, Loscalzo J. Homocyteine and atherothrombosis. N Engl 7 Med 1998;338:1042-50.

30. Herrmann $W$. The importance of hyperhomocysteinemia as a risk factor for disease: an overview. Clin Chem Lab Med 2001;39:666-74.

31. Boysen G, Brander T, Christensen H, Gideon R, Truelsen T. Homocysteine and risk of recurrent stroke. Stroke 2003;34:1258-61.

32. Tanne D, Haim M, Goldbout U, Boyko V, Doolman R, Adler Y, et al. Prospective study of serum homocysteine and risk of ischemic stroke among patients with preexisting coronary heart disease. Stroke 2003;34:632-6.

33. Sasaki T, Watanabe M, Nagai Y, Hoshi T, Takasawa M, Nukata M, et al. Association of plasma homocysteine concentration with atherosclerotic carotid plaques and lacunar infarction. Stroke 2002;33: 1493-6.

34. Fallon UB, Virtamo J, Young I, McMaster D, Ben-Shlomo Y, Wood N, et al. Homocysteine and cerebral infarction in Finnish male smokers. Stroke 2003;34:1359-63.

35. Fassbender K, Mielke O, Bertsch T, Nafe B, Froschen S, Hennerici M. Homocysteine in cerebral macroangiopathy. Lancet 1999;353:1586-7.

36. Vermeer SE, Van Dijk EJ, Koudstaal PJ, Outkerk M, Hofman A, Clarke R, et al. Homocysteine, silent brain infarcts, and white matter lesions: the Rotterdam Scan Study. Ann Neurol 2002;51:285-9.

37. Den Heijer T, Vermeer SE, Clarke R, Outkerk M, Koudstaal PJ, Hofman A, et al. Homocysteine and brain atrophy on MRI of non-demented elderly. Brain 2003;126:170-5.

38. Snowdon DA, Tully CL, Smith CD, Reiley K, Markesbery WR. Serum folate and the severity of atrophy of the neocortex in Alzheimer disease: findings from the Nun study. Am 7 Clin Nutr 2000;71:993-8.

39. Lokk J. News and views of folate and elderly persons. 7 Gerontol A Biol Sci Med Sci 2003;58(4):354-61.

40. Sachdev PS, Valenzuela M, Wand XL, Looi JC, Brodaty H. Relationship between plasma homocysteine levels and brain atrophy in healthy elderly individuals. Neurology 2002;58:1539-41.

41. Hogervorst E, Ribeiro HM, Molyneux A, Budge M, Smith AD. Plasma homocysteine levels, cerebrovascular risk factors, and cerebral white matter changes (leukoaraiosis) in patients with Alzheimer disease. Arch Neurol 2002; 59:787-93.

42. Stabler SP, Marcell PD, Podell ER, Allen RH, Savage DG, Lindenbaum J. Elevations of total homocysteine in the serum of patients with cobalamin or 
folate deficiency detected by capillary gas chromatography-mass spectrometry. 7 Clin Invest 1988;81:466-74.

43. Green R, Kinsella LJ. Current concepts in the diagnosis of cobalamin deficiency. Neurology 1995;45:1435-40.

44. Lindenbaum J, Rosenberg IH, Wilson PWF, Stabler SP, Allen RH. Prevalence of cobalamin deficiency in the Framingham elderly population. Am 7 Clin Nutr 1994;60:2-11.

45. Pennypacker LC, Allen RH, Kelly JP, Matthews LM, Grigsby J, Kaye K, et al. High prevalence of cobalamin deficiency in elderly outpatients. 7 Am Geriatr Soc 1992;40:1197-204.

46. Wright JD, Bialostosky K, Gunter EW, Carroll MD, Najjar MF, Bowman BA, et al. Blood folate and vitamin B12: United States, 1988-94. Vital Health Stat 11 1998;243:1-78.

47. Healton EB, Savage DG, Brust JCM, Garrett TJ, Lindenbaum J. Neurologic aspects of cobalamin deficiency. Medicine 1991;70 229-44.

48. Joosten K, van den Berg A, Riezler R, Naurath HJ, Lindenbaum J, Stabler SP, et al. Metabolic evidence that deficiencies of vitamin B12 (cobalamin), folate, and vitamin B6 occur commonly in elderly people. Am 7 Clin Nutr 1993; 58:468-76.

49. Allen RH, Stabler SP, Savage DG, Lindenbaum J. Elevation of 2-methylcitric acid I and II levels in serum, urine, and cerebrospinal fluid of patients with cobalamin deficiency. Metabolism 1993;42:978-88.

50. Homocysteine lowering trialists' collaboration. Lowering blood homocysteine with folic acida based supplements: meta-analysis of randomized trials. BMF 1998;316:894-8.

51. Garcia A, Evans L, Paris-Pombo A, Freedman M. Is low dose oral cobalamin enough to normalize cobalamin levels and function in the elderly? 7 Am Geriatr Soc 2002;50:1401-4.

52. Garcia A, Pulman K, Zanibbi K, Day A, Galaraneau L, Freedman M. Cobalamin reduces homocysteine in older adults on folic acid-fortified diet: a pilot, double-blind, randomized, placebo-controlled trial [letter]. 7 Am Geriatr Soc 2004;52(8):1410-2.

53. Wilcken DEL, Wilcken B. B vitamins and homocysteine in cardiovascular disease and aging. Ann N Y Acad Sci 1998;854:361-70.

54. Van der Griend R, Biesma DH, Haas FJ, Faber JA, Duran M, Meuwissen OJ, et al. The effect of different treatment regimens in reducing fasting and postmethionine-load homocysteine concentrations. 7 Intern Med 2000;238:223-9.

55. Kelly PJ, Shih VE, Kistler JP, Barron M, Lee H, Mandell R, et al. Low vitamin B6 but not homocysteine is associated with increased risk of stroke and transient ischemic attack in the era of folic acid grain fortification. Stroke 2003:34:51-4.

56. Choumenkovitch SF, Jacques PF, Nadeau MR, Wilson PW, Rosenberg IH, Selhub J. Folic acid fortification increases red blood cell folate concentrations in the Framingham study. 7 Nutr 2001;131:3277-80.

57. Hirsch S, de la Maza P, Barrera G, Battas V, Petermann M, Bunout D. The Chilean flour folic acid fortification program reduces serum homocysteine levels and masks vitamin B-12 deficiency in elderly people. 7 Nutr 2002;132(2):289-91.

58. Ray JG, Cole DEC, Boss SC. An Ontario-wide study of vitamin B12, serum folate, and red cell folate levels in relation to plasma homocysteine: Is a preventable health issue on the rise? Clin Biochem 2000;33:337-43.

59. Zanibbi K, Day A, Geik S, Perret J, Garcia A. Effects of the Canadian folic acid fortification program in the elderly [abstract]. Geriatrics Today 2004;7:678. Presented at the annual meeting of the Canadian Geriatric Society; Toronto; 2004 May 28-30.

60. Choumenkovitch SF, Selhub J, Wilson PW, Rader JI, Rosenberg IH, Jacques PF. Folic acid intake from fortification in United States exceeds prediction. $\mathcal{F}$ Nutr 2002;132:2792-8.

61. Jaques PF, Selhub J, Bostom AG, Wilson PW, Rosenberg IH. The effect of folic acid fortification on plasma folate and total homocysteine concentrations. N Engl 7 Med 1999;340:1449-54.

62. Frosst P, Blom HJ, Milos R, Goyette P, Sheppard CA, Matthews RG, et al. A candidate genetic risk factor for vasclar disease: a common mutation in methyltetrahydrofolate reductase. Nat Genet 1995;10:111-3.

63. Ma J, Stampfer MJ, Hennekens CH. Methyltetrahydrofolate reductase polymorphism, plasma folate, homocysteine and risk of myocardial infarction in US physicians. Circulation 1996;94:2410-6.

64. McIlroy SP, Dynan KB, Lawson JT, Patterson CC, Passmore AP. Moderately elevated plasma homocysteine, methyltetrahydrofolate reductase genotype and risk for stroke, vascular dementia, and Alzheimer's disease in Northern Ireland. Stroke 2002;33:2351-6.

65. Kelly PJ, Rosand J, Kistler JP, Shih VE, Silveira S, Plomaritoglou A, et al. Homocysteine, MTHFR 677 C-T polymorphism, and risk of ischemic stroke: results of a meta-analysis. Neurology 2002;60:529-36.

66. Jacques PF, Kalmbach R, Bagley PJ, Russo GT, Rogers G, Wilson PW, et al. The relationship between riboflavin and plasma total homocysteine in the Framingham Offspring cohort is influenced by folate status and the C677T transition in the methylenetetrahydrofolate reductase gene. 7 Nutr 2002;132:283-8.

67. Russo GT, Friso S, Jacques PF, Rogers G, Cucinotta D, Wilson PW, et al. Age and gender affect the relation between methylenetetrahydrofolate reduc- tase C677T genotype and fasting plasma homocysteine concentrations in the Framingham Offspring Study Cohort. 7 Nutr 2003;133:3416-21.

68. Spotila LD, Jacques PF, Berger PB, Ballman KV, Ellison RC, Rozen R. Age dependence of the influence of methylenetetrahydrofolate reductase genotype on plasma homocysteine level. Am 7 Epidemiol 2003;158:871-7.

69. Percy M, Moalem S, Freedman M, Sommerville M, Azad A, Birkan R, et al. Hereditary hemochromatosis mutations and sporadic Alzheimer disease. Presented at the 8th International Symposium on Metal Ions in Biology and Medicine; Budapest; 2004.

70. Selhub J, Jacques PF, Wilson PW, Rush D, Rosenberg IH. Vitamin status and intake as primary determinants of homocysteinemia in an elderly population. 7AMA 1993;270:2693-8.

71. Jacques PF, Rosenberg IH, Rogers G, Selhub J, Bowman BA, Gunter EW, et al. Serum total homocysteine concentrations in adolescent and adult Americans: results from the third National Health and Nutrition Examination Survey. Am 7 Clin Nutr 1999;69:482-9.

72. Morris MS, Jacques PF, Selhub J, Rosenberg IH. Total homocysteine and estrogen status indicators in the Third National Health and Nutrition Examination Survey. Am 7 Epidemiol 2000;152(2):140-8.

73. Ventura P, Panini R, Verlato C, Scarpetta G, Salvioli G. Hyperhomocysteinemia and related factors in 600 hospitalized elderly subjects. Metabolism 2001;50:1466-71

74. Malouf R, Grimley Evans J, Areosa Sastre A. Folic acid with or without vitamin B12 for cognition and dementia [Cochrane Review]. In: The Cochrane Library. Issue 1. 2004. Chichester (UK): John Wiley and Sons; 2004.

\section{Correspondence to: Dr. Angeles Garcia, Associate Professor,}

Queen's University, St. Mary's of the Lake Hospital,

340 Union St., Kingston ON K7L 5A2; fax 613 544-4017;

garciaa@pccchealth.org

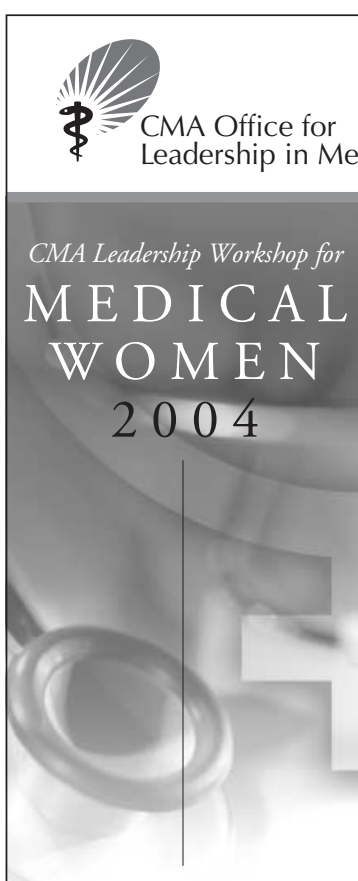

December 3 4, 2004

Westin Harbour Castle Toronto, Ontario

Come join in the $10^{\text {th }}$ anniversary celebration of the CMA Leadership Workshop for Medical Women, a professional development event dedicated exclusively to women physicians with an interest in leadership. In both plenary and small group interactive sessions, learn from leaders in the fields of medicine, law and business.

Featuring special keynote speaker The Right Honourable Beverley McLachlin, Chief Justice of Canada Great networking opportunities, prizes, gifts and more! Registration in this highly successful workshop is limited so register early. For information, or to be placed on the preferred mailing list, contact:

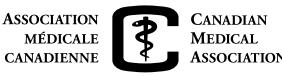

cme.cer
CMA Office for Leadership in Medicine $800663-7336$ or $613731-8610 \times 2261$ Professional Development@cma.ca 